\title{
Human Formation of The Educator During A Pedagogy Undergraduate Course - Outcomes Of An Exploratory Research Study
}

\author{
Lavínia de Melo e Silva Ximenes \\ Application School, Federal University of Pernambuco \\ Recife, Brazil \\ José Policarpo Junior \\ Institute of Human Formation \\ Recife, Brazil \\ André Leite Wanderley \\ Department of Statistics, Federal University of Pernambuco \\ Recife, Brazil
}

\begin{abstract}
This article is a result of an exploratory research study on the feasibility and comprehensiveness of the undergraduate course in Pedagogy promoting the human formation of the educator. The idea of human formation aims to provide the appropriate formation of all constituent aspects of a human being in an undivided way, which includes the formation of cognition, the senses, corporeity, habits, emotional life, the cultivation of relationships and of reflection on the personal meaning of singular human life, and furthermore to understand education itself as a fundamental mediation of formation. In order to verify whether or not the undergraduate course in Pedagogy promotes such training, a convenience sample which consisted of 253 students enrolled in that course at the Federal University of Pernambuco (UFPE), who included first year and final year undergraduates, were interviewed in 2011. A 5-point Likert scale with 41 items was drawn up and called the Scale of Human Formation of the Educator (SHFE). This scale was divided into three sub-scales which were designed to assess: (a) the personal and relational development of the student; (b) understanding the role of the educator, and; (c) the formative understanding of education, school and pedagogy. Statistical tests were carried out to compare the averages of first- and final-year students who were assessed by the three subscales mentioned. It was postulated as a hypothesis that this course would not promote the human formation of the students in accordance with the terms referred to. The results achieved by the research have partially refuted the hypothesis that was formulated, although the differences achieved are not of a significant amplitude.
\end{abstract}

Keywords: human formation, teacher education, pedagogy, education.

\section{INTRODUCTION}

This article is one of the results of an exploratory research study on the meanings and amplitude of the human formation of the educator on the course in Pedagogy.

According to Policarpo Junior and Rodrigues [1] so that education can be understood in tune with human formation, education must be guided by its normative aspect, which is defined not only by the condition in which a human being is found, but also points to the state that he/she is called on to attain by the formation which is appropriate to the nature of his/her being. 
Rodrigues [2] affirms that, for most people, the meaning of education has been reduced, in the contemporary world, to schooling, with all the pragmatic implications of individual human beings adapting and developing abilities so that they can be integrated into the dynamics that shape social life. However, Rodrigues affirms that, conceptually, education is not limited to this, but it also has by implication the symbolic appropriation to live in the world of culture, and social organization among other human beings, which in turn requires each human being to develop the capacity to be governed by the principles of solidarity, of respect for individualities and difference, and of disciplining one's own will, thus exercising one's freedom and autonomy while being fully aware of one's responsibility to be an ethical subject [2].

In order that the idea of human formation does not manifest itself to education as an extrinsic or a priori requirement, its foundation on a close understanding of the human being must be made explicit. The meaning of "close understanding" points to the recognition that no theory or thinker can claim to reach an exhaustive knowledge of the human being, however great their scientific and philosophical contributions to this may be. What is related to this understanding of the human being is a certain formation, the legitimacy of which is based on the degree of its matching up to the nature of such a being [1]. Thus, for example, once we know that a human being possesses such a nature that can only be developed in society, together with other human beings, it becomes clear that this being must appropriate the greatest possible diversity of achievements that shape the historical, social, and cultural world in which men, their fellow beings, inhabit.

For this reason, it is an understandable fact that educational systems are structured with a sense of providing the acquisition, on the part of the particular subjects, of diverse intellectual and attitudinal abilities and disciplines that characterize numerous achievements of the culture; there is no shortage of arguments to justify the scholarly tradition that has been established around this objective in several countries and modern societies. However, cultural achievements do not only require this kind of intellectual formation, beyond which a human being himself is not only a social and cultural being, but also a being-species, i.e. a being of the human species and, also, a personal and unique being.

To this broader understanding of the human being is imposed the correspondence of a formation, the scope of which may be to promote a human form from all the aspects that constitute his/her being. This means that the constitution of the human being is expressed as a parameter of that formation which must, by nature, correspond to it. Authors such as Policarpo Jr \& Röhr [3] call such an understanding the normative aspect of human formation. By using the concept of a normative dimension, it is possible to understand that the very constitution of the human informs us not only what this is, but also what it can and should be. With this understanding, we can understand, for example, that our bodily dimension has certain intrinsic characteristics that demand specific patterns of food, exercise and rest, which, when not observed, imply our health will suffer.

In a similar way, all human beings have an emotional-sentimental dimension that they need to get to know, monitor and guide, in the sense that this aspect can be expressed in the most appropriate and compatible way with the other dimensions of their being. Such aspects need to be cultivated, and need an appropriate formation that cannot happen at random, but rather in a conscious and guided way. According to the foregoing, therefore, such normative reasoning is applied to all the constituent aspects of a human, among which are: (a) his/her organiccorporeal structure; (b) his/her external and internal sensibility which is expressed by means of impulses, emotions and feelings; (c) his/her mental constitution; and (d) his/her 
constitution of non-determined openness to others, to the contexts and sources of meaning for their social, cultural and personal-existential life.

By the fact of being a being-species, a historical, social and cultural being, and a personal being, the complexity of the human imposes the recognition that its constitution demands a formation that integrates all these aspects in a way that corresponds to them and makes sense to every single human being. This understanding points, therefore, to the idea of the integral formation of a human being [4,5], which is not limited to the cognitive aspect, but seeks to integrate the body-organic formation, the formation of emotions and feelings [6], the development of self-awareness, the capacity for openness to the other, and reflection on the values that should govern relations between humans [7]. Thus, the idea of "multiple intelligences" gains relevance [8] as do their specific forms of development and formation.

Once the legitimacy of the integral formation of the human being is admitted, what is equally thrown into relief is the understanding of the normative need for unification or congruence of its diverse aspects or expressions such as thinking, feeling, and acting [4, 9, 10]. Such integration does not, therefore, occur, at random, but in a way that respects a condition in which the human being expresses him/herself and lives in an entire and coherent way. There is no other meaning of the word "individual", on pointing to the desirable state of the particular being who overcomes his/her internal and external schisms by unifying his/her various dimensions. One is, therefore, dealing with the idea of individuation $[11,12]$ that alludes to the sense of the particular human being unifying him/herself by overcoming the divisions between his/her thought, emotions and feelings, body and actions.

No individuation can occur when the particular being lets him/herself be led unconsciously by his/her impulses and emotions, since these in themselves do not have the necessary enlightenment to promote the integration to which every single being is called. The individuation which is expressed by the coherence of individuals therefore requires the orientation of thought, conscious feeling and acting with consequence and responsibility. It is by doing so, therefore, that the process of individuation requires emotional and relational education [13-17], so that the personal being can progressively become familiar with the psychic energy that inhabits him/her, and so become aware of this by using self-observation and self-control. In this way, knowing how to name and recognize what you feel, to experience all feelings and emotions without being carried away by them is the necessary presupposition so that the individual human being can exercise the capacity to monitor and guide them, without either repressing them or falling under their dominion.

Integrating oneself, individuating oneself, being able to monitor one's emotions and acting with awareness are skills or abilities that become more developed as the particular subject starts to cultivate a sound and attentive mind [18-20] or that exercises self-consciousness. Thinking about one's own thinking, feelings and emotions, about one's actions, desires, preferences and values is a fundamental condition for someone to direct his/her own life properly and is, therefore, equally a normative aspect of the human formation to which particular beings are called on to submit themselves. It is equally by means of self-awareness and of the ability to think about all aspects related to their lives that human beings reach the possibility of reflecting on human values and orienting themselves by cultivating these values [21-27] which pave the way for a meaningful and fulfilling life. In this condition, the particular being naturally starts, of his/her own accord, without external coercion, to direct him/herself in the sense of avoiding harm to third parties and to bear him/herself in a valuable way for him/herself and others. None of this, however, can arise without the human being moving in the direction of 
his/her integration, individuation, emotional development and monitoring, and exercise of self-awareness.

In advancing on such a formative path, the particular being will more easily recognize the necessity and validity of cultivating principles such as equality between human beings, the search for truth that enlightens oneself, the valuing of attitudes and practices that are useful to oneself and to others [3].

It is only when the human being commits him/herself and begins the long personal journey of mapping out his/her life and guiding it according to such normative principles, even if he/she can never attain such fulfillment completely, that he/she will be able to recognize freely and autonomously the need and way to open him/herself to the other, his fellow. Certainly, all human beings begin a process of opening themselves to the other long before they are aware of doing so. However, it is precisely because many never reach the understanding of the need for and the richness of the encounter with the other that so many problems and tragedies happen in relationships. Without reaching the minimum capacity to conduct oneself consciously, in an integrated and individuated way, it is difficult for the individual being to be able to establish $\mathrm{him} /$ herself in the condition of establishing relations in which he/she may encounter his/her fellow beings, which necessarily will end up by impoverishing him/her as the human being which he/she is, for, as humans, all are incomplete without the presence of the other.

For this reason, authors such as Erikson [28] and López Quintás [23] have stated, in different ways, that the relations of unity with other human beings need to be cultivated, that is, they do not spring up by chance, and their cultivation requires the individual to have the capacity to move out of his self-centeredness, which can only be achieved when he/she is able to integrate him/herself, to individuate him/herself, to monitor and direct his/her emotional life minimally, and to exercise his self-awareness, for only someone who has achieved such abilities can stop being subjugated by the more primitive forces of an emotional and instinctual character which have no wisdom in themselves to guide human beings.

As López Quintás [23] has stated, in order to establish a relationship with another human being, the individual must cultivate values such as generosity, trust and fidelity, which are qualities that can only arise in someone who acquires and minimally exercises personal congruence. However, if the human being does not demonstrate the capacity to overcome his/her more self-centered tendencies and, therefore, is unable to unify him/herself, to exercise his/her self-awareness and to cultivate the values that invite the celebration of the encounter between human beings, he/she will also not be able to reach the richest level of humanization that requires object relations between people to be overcome [23], thus condemning him/herself to remaining in the condition of self-enclosure that leads to failure, isolation and, at the limit, to depression and despair [28].

In the light of the foregoing, the concept of human formation brings with it the understanding that a human being is called to develop ontogenetically and philogenetically, personally and socially, in a manner that is congruent with his/her unique, universal and social nature. This understanding includes the integral development of the human being in his/her bodily, affective, behavioral, cognitive-reflective, attitudinal, relational and interpersonal aspects [8, 46]. This formation of the singular entity is allied with social and citizen formation [29, 30]. Without the former, the latter cannot truly develop into a single entity. Conversely, the full development of individuality can only take place in the midst of social participation. 
One of the major obstacles to consolidating this integral vision of formation lies in the fact that there are several articles from the educational field that deal with the necessary relationship between education, society and citizenship, without specifying the ways in which this relationship is expressed in the integrated formation of the singular human being, according to Rodrigues [2], Policarpo Junior [7] and Galeffi [31]. Consequently, the integral human formation of the educator is the object of even fewer studies, an aspect that is all the more necessary when one takes into account the corollary that without an educator who is apt at personally performing the task of singular, social and civilizing formative mediation, little can be done to ensure the human formation of students.

The legal and regulatory frameworks for educating and training the educator in Brazil, such as Law no. 9.394/96 [32] and the National Curricular Guidelines for courses in Pedagogy [33], state in generic terms the integrality of the educator's formation, although without detailing the formative requisites and consequences in all the constituent aspects of the singular being, but rather they translate this into conceptual, technical-procedural and ethical-professional contents [34]. However broad the contents may be, it is seen that an explicit mention of the contribution of the academic formation to the personal formation of the educator is absent, in the sense that this can progress in his/her process of individuation, with the necessary implications for the congruence between his/her mental, affective, attitudinal and relational life, without personal singular and existential knowledge of which, no educator can contribute consciously to the formation of his/her students in the same terms $[26,5]$.

It follows from the foregoing that the formation of the educator intrinsically involves his/her personal dimension, the implication of which, consequently, is that each individual has the capacity to understand and recognize in him/herself his/her incongruities, lack of discipline of the will and incompatibility between values and attitudes, not so as to consider them as substances, but rather to recognize the importance of the formative journey in relation to him/herself, which reveals to him/her the progress that has never been fully realized of the congruence between thinking, feeling, acting, and relating to others [6].

Human formation is therefore made up of humanization in the sense of rendering humanized everything that, despite being human, is still in a primitive state, such as self-centeredness, ignorance of the other, instinctive and non-sublimated volitions. In this task which is never completely fulfilled, education assumes the strict sense of the Greek concepts of paideia and areté, of the human being being called on so that he/she can fully develop the humanity that is appropriate to him/her and which by vocation should be his/her own [35, 36].

To this personal comprehension and development, although these are always partial, the formation of the educator adds an understanding of the function of educating, of being a mediator, among beings that are developing, and of everything that aims to promote such formation in students. Therefore, being an educator is clothed in the authority [37] of a representative of culture - this being conceived in the strict sense of all constructions of the human spirit that are able to cultivate, in each particular being, the seeds of humanity and civilization - vis-à-vis beings who need to be cultivated. It is, therefore, about a knowledge appropriate to and unique to the educator, which exists as a constitutive disposition of his/her personal being vis-à-vis education and students, yet a fruit of the cultivation provided by his/her formation. It is clear, therefore, that this is not about knowledge that is purely conceptual knowledge, but must equally be experiential or existential.

In addition to the personal formation and the cultivation of a way of being that is appropriate to the exercise of educating, the educator's human formation is complemented by the personal 
understanding of education, pedagogy and school as expressions and means of promoting the humanization of learners in a process that includes and goes beyond competitive or critical adaptation to the existing one. Thus, education as a concept and process [38, 39], pedagogy as its science and theorization $[40,41]$ and school as an institutional space for its realization [42, 22], are now conceived as fundamental moments of the process of the human formation of learners, this being an understanding that becomes inseparable from the formation of the educator.

In the light of the foregoing, this research study investigated, in an exploratory way, the possibility and coverage of the human formation of the educator based on the Pedagogy course, by emphasizing three main aspects: (a) the personal and relational development of the educator; (b) understanding the nature of his/her formative mediation among students, or his/her role as an educator; (C) understanding education, pedagogy and school as a means of achieving this formation.

Considering, because of what has been set out in the foregoing, the fact that the conception of human formation is not widely diffused in the educational field [7], it was assumed as a research hypothesis that the course in Pedagogy would not promote, in the rigorous sense of Humanization already presented, the formation of teachers in the three aspects mentioned above.

\section{Sample}

\section{METHOD}

In order to ascertain, in an exploratory way, the scope and limits of human formation in the process of forming the educator, a convenience sample of 253 students $(n=253)$ was compiled from the Morning, Afternoon and Evening classes of the course in Pedagogy at UFPE. This total was divided into 109 first-year students, i.e., those who had enrolled in the first semester of this course, and 144 final-year students, i.e., those who had enrolled in the last semester. These students were interviewed by means of a written questionnaire during the first and second semesters of the 2011 academic year. An effort was made to interview all the first- and finalyear students of a specific semester, although not all were reached due to some of them being absent on the dates on which the questionnaires were applied. The distribution of the sample by gender, time of day of class and year group (first- and final-year) is given in Tables 1 and 2:

Table 1. Distribution of the Sample by Year Group and Gender of the Students

\begin{tabular}{|l|c|c|c|c|c|}
\hline & \multicolumn{2}{|c|}{ First-Year } & \multicolumn{2}{c|}{ Final-Year } & Totals \\
\hline Female & 100 & $39.5 \%$ & 128 & $50.6 \%$ & $228(90.1 \%)$ \\
\hline Male & 9 & $3.6 \%$ & 16 & $6.3 \%$ & $25(9.9 \%)$ \\
\hline Totals & 109 & $43.1 \%$ & 144 & $56.9 \%$ & $253(100 \%)$ \\
\hline
\end{tabular}

Table 2. Distribution of the Sample by Year Group and Time of Day that Students Attended Classes

\begin{tabular}{|l|c|c|c|c|c|}
\hline & \multicolumn{2}{|c|}{ First-Year } & \multicolumn{2}{c|}{ Final-Year } & Totals \\
\hline Morning & 42 & $16.6 \%$ & 39 & $15.4 \%$ & $81(32 \%)$ \\
\hline Afternoon & 30 & $11.9 \%$ & 27 & $10.7 \%$ & $57(22.6 \%)$ \\
\hline Evening & 37 & $14.6 \%$ & 78 & $30.8 \%$ & $115(45.4 \%)$ \\
\hline Totals & 109 & $43.1 \%$ & 144 & $56.9 \%$ & $253(100 \%)$ \\
\hline
\end{tabular}


In the light of what is presented in Tables 1 and 2, it is observed that the sample consists predominantly of female participants (90\%) and that the evening class is the one with the highest number of enrolled students (45\%).

As for age, the sample is distributed between those whose minimum age was 17 years old and those whose maximum age was 52 years old, the first and third quartiles reaching the values of 23 and 31 , respectively.

\section{Instrument}

In order to evaluate the hypothesis presented that the Pedagogy course would not promote the human formation of educators, 41 items were proposed, with responses on a five-point Likert scale, entitled Scale of Human Formation of the Educator (SHFE). The items of this scale were drawn up and scored either in direct and increasing order (A), or in reverse and decreasing order (D), in accordance with whether they expressed a positive or negative affirmation of the concept that it was intended to measure.

Given that the research instrument should cover the three aspects mentioned in the research hypothesis - (a) the personal and relational development of the educator; (b) an understanding of the educator's formative function; (c) the formative understanding of education, pedagogy and school - the SHFE was organized into three subscales, each of which gave rise to an index, which was intended to measure the three aspects mentioned above, namely: (a) an Index of Personal and Relational Development (Iprd), with 13 items; (b) an Index of Understanding the Role of the Educator (Iure), with 11 items, and; (c) Index of Understanding Education, School and Pedagogy (Iuesp), with 17 items.

The items of each subscale were validated by measuring what the positive and statistically significant correlation of each of them was with the average of all the other constant items of each subscale. The test selected to measure this correlation was that of Spearman's rank correlation coefficient $\left(r_{s}\right)[43]$.

The conventional limit value of 0.05 was adopted as the criterion of statistical significance for this and all other research tests. All tests were performed using the statistical software package $\mathrm{R}$, version 2.15.1 [44].

After validating the items, the internal consistency of each index was checked by the Cronbach Alpha test $(\alpha)$, which has an interval variation of 0 to 1 , the minimum parameter acceptable for the human sciences which was adopted as the criterion of acceptance of each index [45], at a value of 0.6. The three indices - Iprd, Iure, Iuesp - reached the minimum level of consistency, with, respectively, the following Cronbach's Alpha values: $0.68 ; 0.68$ and 0.61.

The distribution of the items by the three SHFE indices is shown in Tables 3, 4 and 5, including the statistically significant correlation values of each of them with the average of the respective index. The description of each item is followed by the indication (D), as its content consists of a negation of the concept that the index represents and, therefore, the answers to the item have to be evaluated in a descending way $(5,4,3,2,1)$, or (A) if the content of the item positively affirms the concept represented by the index and, therefore, its answers have to be evaluated in an ascending way $(1,2,3,4,5)$. 
Table 3 - Items that make up the SHFE Index of Personal and Relational Development (Iprd) and their correlations (Spearman's coefficients) with the mean

\begin{tabular}{|l|c|}
\hline \multicolumn{1}{|c|}{ Item } & $\begin{array}{c}\text { Correlation } \\
\left.\text { ( } \mathrm{r}_{\text {s }}\right)^{*}\end{array}$ \\
\hline $\begin{array}{l}\text { It is important to know the people and the realities we live in to make } \\
\text { the choices that meet our desires and preferences. (D) }\end{array}$ & 0.29 \\
\hline $\begin{array}{l}\text { The distinction between virtue and vice is each person's decision. There } \\
\text { is not a general criterion for this. (D) }\end{array}$ & 0.33 \\
\hline $\begin{array}{l}\text { In a situation of conflict, dialogue will ensure that whoever uses the } \\
\text { better arguments will prevail. (D) }\end{array}$ & 0.43 \\
\hline $\begin{array}{l}\text { When an unusual situation happens, it is best to ignore it and follow } \\
\text { through on our project of life: to be happy. (D) }\end{array}$ & 0.46 \\
\hline $\begin{array}{l}\text { The acquisition of knowledge and a successful career are fundamental to } \\
\text { establishing relationships with whomsoever we wish. (D) }\end{array}$ & 0.45 \\
\hline $\begin{array}{l}\text { We develop as human beings when we succeed in our endeavors and we } \\
\text { can control and dominate them. (D) }\end{array}$ & 0.53 \\
\hline $\begin{array}{l}\text { In an individualistic and consumer society, one must be aware of } \\
\text { opportunities to get on in life. (D) }\end{array}$ & 0.42 \\
\hline $\begin{array}{l}\text { Personal success and happiness depend fundamentally on broader } \\
\text { social conditions; the individual's power to choose and decide is small in } \\
\text { this regard. (D) }\end{array}$ & 0.38 \\
\hline $\begin{array}{l}\text { Our self-knowledge and humanization depend fundamentally on } \\
\text { satisfying our emotions and feelings. (D) }\end{array}$ & 0.52 \\
\hline $\begin{array}{l}\text { Conflicts between people are determined socially, so the individual can } \\
\text { do little to solve them. (D) }\end{array}$ & 0.27 \\
\hline $\begin{array}{l}\text { Obtaining success in most of one's endeavors makes a person successful } \\
\text { (D). }\end{array}$ & 0.55 \\
\hline Emotions are not to be understood, but to be lived. (D) & 0.59 \\
\hline $\begin{array}{l}\text { If anyone wants me to treat him/her cordially, he/she must treat me in } \\
\text { the same way. (D) }\end{array}$ & 0.43 \\
\hline
\end{tabular}

* All correlations were statistically significant. 
Table 4 - Items that compose the SHFE Index of Understanding of the Role of the Educator (Iure) and its correlations (Spearman's coefficients) with the mean

\begin{tabular}{|l|c|}
\hline \multicolumn{1}{|c|}{ Item } & $\begin{array}{c}\text { Correlation } \\
\left.\text { ( } \mathrm{r}_{\mathrm{s}}\right)^{*}\end{array}$ \\
\hline $\begin{array}{l}\text { It is the function of the educator to promote the reflective and cognitive } \\
\text { development of the learner; emotional, attitudinal and value aspects are } \\
\text { the responsibility of the family and the learner him/herself. (D) }\end{array}$ & 0.62 \\
\hline $\begin{array}{l}\text { Being an educator is magnificent, but the real conditions of education } \\
\text { and teaching make such a profession frustrating and aversive. (D) }\end{array}$ & 0.26 \\
\hline $\begin{array}{l}\text { It is important that the teacher be generous, patient and inspire } \\
\text { confidence, but the real bottom line is that he/she is competent in the } \\
\text { content he/she will teach. (D) }\end{array}$ & 0.58 \\
\hline $\begin{array}{l}\text { When the educator is fully competent and the educational circumstances } \\
\text { are favorable, the student's personal formation and development are } \\
\text { guaranteed. (D) }\end{array}$ & 0.53 \\
\hline $\begin{array}{l}\text { Being a teacher is a profession like any other: being a good teacher is } \\
\text { one thing; having personal integrity and coherence, is something else. } \\
\text { (D) }\end{array}$ & 0.41 \\
\hline $\begin{array}{l}\text { The ideal of becoming a better person is up to each individual; it is for } \\
\text { education and the educator to prepare a person for the world of work } \\
\text { and the development of citizenship. (D) }\end{array}$ & 0.60 \\
\hline $\begin{array}{l}\text { Although education happens in a context of relationships, it is } \\
\text { sometimes necessary for the teacher to impose his or her values on the } \\
\text { students. (D) }\end{array}$ & 0.54 \\
\hline $\begin{array}{l}\text { The meaning of pedagogical practice and teaching is given by teaching } \\
\text { curriculum content appropriately, and it is this which is the primary } \\
\text { competence of the educator. (D) }\end{array}$ & 0.64 \\
\hline $\begin{array}{l}\text { The teacher's function is to teach the curricular content for which } \\
\text { he/she is responsible well, without involving him/herself with subjects } \\
\text { that extrapolate such activity. (D) }\end{array}$ & 0.30 \\
\hline $\begin{array}{l}\text { What is a requirement of the formation of the educator is the Socratic } \\
\text { maxim: know yourself. (A) }\end{array}$ & 0.14 \\
\hline $\begin{array}{l}\text { The mature educator exercises his teaching in the sense of promoting } \\
\text { the homogeneity of his students. (D) }\end{array}$ & 0.50 \\
\hline
\end{tabular}

* All correlations were statistically significant.

It is observed, with reference to Table 4, that three items showed a weak correlation, while the others presented a moderate to strong correlation with the average of all of them. 
Table 5 - Items that make up the SHFE Index of Understanding of Education, School and Pedagogy (Iuesp) and its correlations (Spearman's coefficients) with the mean

\begin{tabular}{|c|c|}
\hline Item & $\begin{array}{c}\text { Correlation } \\
\left(r_{s}\right)^{*}\end{array}$ \\
\hline $\begin{array}{l}\text { It is not up to education to foster self-knowledge of emotions and } \\
\text { feelings on the part of the student - this is the task of Psychology. (D) }\end{array}$ & 0.34 \\
\hline $\begin{array}{l}\text { The matching up of fields of knowledge in a collective and } \\
\text { interdisciplinary way meets the academic, formative and humanizing of } \\
\text { the educator. (A) }\end{array}$ & 0.32 \\
\hline $\begin{array}{l}\text { The human being has several dimensions, but not all of them can be } \\
\text { objects of pedagogical formation. That is why the Pedagogy course } \\
\text { should give priority to cognitive and social aspects. (D) }\end{array}$ & 0.54 \\
\hline $\begin{array}{l}\text { Academic formation prepares the educator for a harsh reality: some } \\
\text { individuals will never become good people, for they were born with a } \\
\text { wicked nature. (D) }\end{array}$ & 0.44 \\
\hline $\begin{array}{l}\text { It is very important that the school environment provides a climate of } \\
\text { freedom so that everyone can satisfy their wishes. (D) }\end{array}$ & 0.26 \\
\hline $\begin{array}{l}\text { The human being is not only social and mental; he/she has several other } \\
\text { dimensions that must also be the object of formation in Pedagogy. (A) }\end{array}$ & 0.33 \\
\hline $\begin{array}{l}\text { The goal of education is formation for citizenship - the other aspects, } \\
\text { although important, are secondary. (D) }\end{array}$ & 0.38 \\
\hline $\begin{array}{l}\text { It is important that education should teach children and adolescents not } \\
\text { to waste their freedom to fully realize their wishes and preferences. (D) }\end{array}$ & 0.31 \\
\hline $\begin{array}{l}\text { Despite the importance of the family for educational purposes, well- } \\
\text { founded learning at school makes up for deficiencies in the family. (D) }\end{array}$ & 0.41 \\
\hline $\begin{array}{l}\text { Pedagogy cannot be exercised as a field of knowledge and formation if it } \\
\text { is not clear about human nature and its formative goal. (A) }\end{array}$ & 0.30 \\
\hline $\begin{array}{l}\text { The purpose of education is to give us the skills to carry out projects and } \\
\text { satisfy wishes more easily. (D) }\end{array}$ & 0.42 \\
\hline $\begin{array}{l}\text { There are so many social, family, and personal obstacles that education } \\
\text { cannot form for life. (D) }\end{array}$ & 0.43 \\
\hline $\begin{array}{l}\text { Intervening in the sense of humanizing individuals is a personal } \\
\text { initiative of some professionals, but it is not a priority of the educator's } \\
\text { process of academic formation. (D) }\end{array}$ & 0.45 \\
\hline $\begin{array}{l}\text { Education should not be defined, first and foremost, in political, social or } \\
\text { economic terms, but rather in accordance with the aspects and } \\
\text { dimensions that make up human nature. (A) }\end{array}$ & 0.31 \\
\hline $\begin{array}{l}\text { It is the fundamental objective of education to provide conditions for the } \\
\text { individual to achieve professional achievement and financial security. } \\
\text { (D) }\end{array}$ & 0.46 \\
\hline $\begin{array}{l}\text { The ideas of justice, solidarity and generosity are beautiful, but we } \\
\text { cannot expect them to be formed by means of education in a capitalist } \\
\text { system. (D) }\end{array}$ & 0.40 \\
\hline $\begin{array}{l}\text { The formation in Pedagogy implies working on the formation of the } \\
\text { human being in his/her cognitive, emotional/sentimental, evaluative, } \\
\text { attitudinal, and spiritual aspects. (A) }\end{array}$ & 0.35 \\
\hline
\end{tabular}

* All correlations were statistically significant.

It is observed, with reference to Table 5 , that two items showed a weak correlation, while the others had a moderate correlation with the average of all of them. 


\section{Procedures}

After having validated the items and the internal consistency of the indices, the next step was to calculate the correlations between the indices in order to verify if the tendencies towards growth and diminution in one of them would or would not be associated with the same tendencies in the other two. The Pearson Correlation Test (r) was used to evaluate such correlations, both among the first- and among the final-year students of the Pedagogy course. It is assumed, based on the Central Limit Theorem, that the indices follow a Gaussian distribution.

Thereafter, an attempt was made to evaluate if and to what extent the Pedagogy course would provide the human formation of the educator, in accordance with the spectrum covered by the three indices above-mentioned. The T-test of means was used as a criterion for this measurement, in its one-tailed mode, insofar as the hypothesis was formulated in the sense that the final-year students would not have a greater development in these indices. Therefore, it was sufficient to measure if the means of the final-year students were greater or not than those of the first-year students.

\section{Correlations between the indices}

\section{RESULTS}

Tables 6 and 7 present the values of the statistically significant correlations between the indices measured between the first year and the final year students.

Table 6. Correlation (Pearson) between the Indices (first-year students)

\begin{tabular}{|c|c|c|c|}
\hline & Iprd & Iure & Iuesp \\
\hline Iprd & 1.00 & 0.59 & 0.58 \\
\hline Iure & 0.59 & 1.00 & 0.49 \\
\hline Iuesp & 0.58 & 0.49 & 1.00 \\
\hline
\end{tabular}

Table 7. Correlation (Pearson) between the Indices (final-year students)

\begin{tabular}{|c|c|c|c|}
\hline & Iprd & Iure & Iuesp \\
\hline Iprd & 1.00 & 0.56 & 0.50 \\
\hline Iure & 0.56 & 1.00 & 0.62 \\
\hline Iuesp & 0.50 & 0.62 & 1.00 \\
\hline
\end{tabular}

The existence of a moderate to strong correlation between the indices is verified in both conditions (first year and final year students), which indicates the tendency of association between the concepts which they represent.

\section{Tests of means}

As for the possible differences in means between first- and final-year students, we sought to measure them, by means of the T test, in three situations: (a) between first- and final-year students in general; (b) between first- and final-year students, considering the variable age as a control factor, and; (c) between first- and final-year students, considering the time of day of class variable as a control factor.

Table 8 presents the parameters of the one-tailed $\mathrm{T}$ tests carried out on the three indices, between the groups of first- and final-year students. 
Table 8. Parameters (mean (M), standard deviation ( $S$ ), $T$ and $p$ ) values of the $T$-Tests, for the three indices, between the means of first- and final-year students

\begin{tabular}{|c|c|c|c|c|c|c|}
\hline Indices & \multicolumn{2}{|c|}{$\begin{array}{c}\text { First-year students } \\
\text { (n=109) }\end{array}$} & \multicolumn{2}{c|}{$\begin{array}{c}\text { Final-Year students } \\
\text { (n=144) }\end{array}$} & T Value & p Value \\
& $\mathbf{M}$ & $\mathbf{S}$ & $\mathbf{M}$ & & \\
\hline Iprd & 2.99 & 0.63 & 3.23 & 0.67 & -2.87 & 0.0045 \\
\hline Iure & 3.01 & 0.62 & 3.42 & 0.73 & -4.82 & 0 \\
\hline Iuesp & 3.78 & 0.47 & 3.92 & 0.49 & -2.31 & 0.0218 \\
\hline
\end{tabular}

It is observed that the tests indicated a significant difference in the three indices between firstand final-year students, with the latter achieving a higher score and, therefore, presenting the tendency of greater development in the three aspects of human formation measured by the indices in question, which goes against the central hypothesis of this study.

Given that the final-year students tend to be, on average, older than the first-year students simply because of the passage of time, an attempt was made to verify the possibility that the greater development in these indices was simply due to the higher average age as between the first- and final-year students. For this purpose, three types of T-tests were performed. First, the sample was divided, without distinction between first- and final-year students, between students who were younger and older than the median of the distribution (26.3) by age, by measuring the difference between the two in the three indices under consideration. Secondly, the same tests were applied to the younger and older students only of the first-year group, and also among younger and older students of the final-year group. Thirdly, the tests were redone with the object of distinguishing between younger first-year students and younger final-year students, and also among older first-year and final-year students. Tables 9 to 13 present these results.

Table 9. Parameters (mean (M), T and p values of the T-Tests, for the three indices, between the means of Students who were Younger and Older than the median (26.3) age of the sample

\begin{tabular}{|c|c|c|c|c|}
\hline Indices & $\begin{array}{c}\text { Younger } \\
(\mathbf{n = 1 2 7}) \\
\mathbf{M}\end{array}$ & $\begin{array}{c}\text { Older } \\
\mathbf{( n = 1 2 6 )} \\
\mathbf{M}\end{array}$ & T Value & $\mathbf{p}$ Value \\
\hline Iprd & 3.04 & 3.21 & -2.08 & 0.0386 \\
\hline Iure & 3.20 & 3.28 & -0.88 & $0.38^{*}$ \\
\hline Iuesp & 3.80 & 3.93 & -2.15 & 0.0324 \\
\hline
\end{tabular}

* Not significant, $\mathbf{p}>0.05$.

Table 10. Parameters (mean (M), $T$ and $p$ values) of the $T$-Tests, for the three indices, among the means of First-Year Students who were younger and older than the median (26.3) age of the sample

\begin{tabular}{|c|c|c|c|c|}
\hline Indices & $\begin{array}{c}\text { Younger } \\
(\mathbf{n = 7 3 )} \\
\mathbf{M}\end{array}$ & $\begin{array}{c}\text { Older } \\
\mathbf{( n = 3 6 )} \\
\mathbf{M}\end{array}$ & T Value & p Value \\
\hline Iprd & 2.91 & 3.16 & -2.09 & 0.0398 \\
\hline Iupe & 3.03 & 2.97 & 0.42 & $0.6736^{*}$ \\
\hline Iuesp & 3.73 & 3.87 & -1.49 & $0.1407^{*}$ \\
\hline
\end{tabular}

* Not significant, $p>0.05$. 
Table 11. Parameters (mean (M), T and p values) of the T-Tests, for the three indices, among the means of Final-Year Students who were younger and older than the median (26.3) age of the sample

\begin{tabular}{|c|c|c|c|c|}
\hline Indices & $\begin{array}{c}\text { Younger } \\
(\mathbf{n = 5 4 )} \\
\mathbf{M}\end{array}$ & $\begin{array}{c}\text { Older } \\
\mathbf{( n = 9 0 )} \\
\mathbf{M}\end{array}$ & T Value & $\mathbf{p}$ Value \\
\hline Iprd & 3.22 & 3.24 & -0.17 & $0.8629^{*}$ \\
\hline Iure & 3.44 & 3.41 & 0.29 & $0.7698^{*}$ \\
\hline Iuesp & 3.88 & 3.95 & -0.81 & $0.4203^{*}$ \\
\hline
\end{tabular}

* Not significant, $\mathrm{p}>0.05$.

Tables 9 to 11 show that, in the sample studied, the age component seems to contribute at least to the students' greater personal and relational development (Iprd). It is observed, however, that the course itself cannot be disregarded as to its contribution either, since, among the final year students, there is no significant difference between younger and older students in any index.

Table 12. Parameters (mean (M), T and p values) of the T-Tests, for the three indices, among the means of First-Year Students and Final-Year Students who were Younger than the median (26.3)

age of the sample

\begin{tabular}{|c|c|c|c|c|}
\hline Indices & $\begin{array}{c}\text { Younger First- } \\
\text { Year Students } \\
\text { (n=73) } \\
\mathbf{M}\end{array}$ & $\begin{array}{c}\text { Younger Final- } \\
\text { Year Students } \\
\text { (n=54) } \\
\mathbf{M}\end{array}$ & T Value & p Value \\
\hline Iprd & 2.91 & 3.22 & -2.61 & 0.0102 \\
\hline Iure & 3.03 & 3.44 & -3.35 & 0.0011 \\
\hline Iuesp & 3.73 & 3.88 & -1.62 & $0.1085^{*}$ \\
\hline
\end{tabular}

* Not significant, $\mathrm{p}>0.05$.

Table 13. Parameters (mean (M), $T$ and $p$ values) of the $T$-Tests, for the three indices, among the means of First-Year Students and Final-Year Students who were Older than the median (26.3)

age of the sample

\begin{tabular}{|c|c|c|c|c|}
\hline Indices & $\begin{array}{c}\text { Older First- } \\
\text { Year Students } \\
\text { (n=73) } \\
\mathbf{M}\end{array}$ & $\begin{array}{c}\text { Older Final- } \\
\text { Year Students } \\
\text { (n=54) } \\
\mathbf{M}\end{array}$ & T Value & p Value \\
\hline Iprd & 3.16 & 3.24 & -0.69 & $0.489^{*}$ \\
\hline Iure & 2.97 & 3.41 & -3.43 & 0.0009 \\
\hline Iuesp & 3.87 & 3.95 & -0.80 & $0.4238^{*}$ \\
\hline
\end{tabular}

* Not significant, $\mathrm{p}>\mathbf{0 . 0 5}$.

Once again, it is observed, from Table 12, that the course contributes in some way, at least as regards personal and relational development (Iprd) and the understanding of the role of the educator (Iure), for the formation of the educator since there is a statistically significant difference in these two indices between first- and final-year students who are younger than the median of the distribution by age. On the other hand, the contribution of age, at least for the Iprd cannot be denied, since, in accordance with Table 13, there is no significant difference, in this index, between first- and final-year students who are older than the median of the distribution by age. Thus, the evidence points to the trend that age and course contribute at least to Iprd. On the other hand, it is observed that, as far as the Iure index is concerned, the tendency is for the Pedagogy course to promote the development of this index, since there is a 
significant difference between the first- and final-year students, whether they are younger or older than the median of the distribution by age.

Finally, an attempt was made to measure the possible difference between first- and final-year students, regarding the three indices, when the time of day of the class was the control variable, bearing in mind that there is a tendency for the evening course to be taught with a lower hourly load than the daytime one, because in the case of the UFPE Pedagogy course, there are four hours of classes per day available in the morning and afternoon, while in the evening the duration of classes drops to three hours. In addition, evening class students are more likely to work during the day, thus arriving at university in the evening more tired than their morning and afternoon peers. That said, the same tests were performed among the firstand final-year students of the three times of day for classes. Tables 14 to 16 present the results achieved.

Table 14. Parameters (mean (M), $T$ and $p$ values) of the $T$-Tests, for the three indices, among the means of First-Year Students and Final-Year Students of the Morning classes

\begin{tabular}{|c|c|c|c|c|}
\hline Indices & $\begin{array}{c}\text { First Year } \\
\text { Students } \\
(\mathbf{n = 4 2 )} \\
\mathbf{M}\end{array}$ & $\begin{array}{c}\text { Final Year } \\
\text { Students } \\
(\mathbf{n = 3 9 )} \\
\mathbf{M}\end{array}$ & T Value & p Value \\
\hline Iprd & 2.98 & 3.37 & -2.62 & 0.0105 \\
\hline Iupe & 2.92 & 3.56 & -4.26 & 0 \\
\hline Iuesp & 3.77 & 3.99 & -2.07 & 0.0420 \\
\hline
\end{tabular}

* Not significant, $\mathrm{p}>0.05$

Table 15. Parameters (mean (M), T and p values of the T-Tests, for the three indices, among the means of First-Year Students and Final-Year Students of the Afternoon classes

\begin{tabular}{|c|c|c|c|c|}
\hline Indices & $\begin{array}{c}\text { First Year } \\
\text { Students } \\
\text { (n=30) } \\
\mathbf{M}\end{array}$ & $\begin{array}{c}\text { Final Year } \\
\text { Students } \\
\text { (n=27) } \\
\mathbf{M}\end{array}$ & T Value & p Value \\
\hline Iprd & 2.94 & 3.22 & -1.72 & $0.092^{*}$ \\
\hline Iupe & 3.10 & 3.60 & -2.56 & 0.0135 \\
\hline Iuesp & 3.83 & 4.10 & -2.47 & 0.0165 \\
\hline
\end{tabular}

* Not significant, $\mathrm{p}>0.05$

Table 16. Parameters (mean (M), $T$ and $p$ values) of the T-Tests, for the three indices, among the means of First-Year Students and Final-Year Students of the Evening classes

\begin{tabular}{|c|c|c|c|c|}
\hline Indices & $\begin{array}{c}\text { First-Year } \\
\text { Students } \\
\text { (n=37) } \\
\mathbf{M}\end{array}$ & $\begin{array}{c}\text { Final-Year } \\
\text { Students } \\
\text { (n=78) } \\
\mathbf{M}\end{array}$ & T Value & p Value \\
\hline Iprd & 3.05 & 3.17 & -0.83 & $0.4072^{*}$ \\
\hline Iupe & 3.04 & 3.29 & -1.97 & $0.0527^{*}$ \\
\hline Iuesp & 3.75 & 3.83 & -0.72 & $0.4711^{*}$ \\
\hline \multicolumn{4}{|r}{ * Not significant, p $>\mathbf{0 . 0 5}$} \\
\end{tabular}

Tables 14 to 16 provide strong evidence that the conditions offered in the morning class are more favorable to the promotion of the human formation of the educator, while the evening class is less favorable. 


\section{DISCUSSION AND CONCLUSION}

As Tables 6 and 7 presented, a moderate association between the three indices of the study was evidenced. In theoretical terms, such evidence is in line with the idea that the greatest personal and relational development of an educator in formation tends to accompany his/her understanding that the educator's action, the sense of education, of school, and of pedagogy are means to foster the human formation of the learners. Therefore, the three indices of the study have been shown to be important references to analyze the human formation in the process of the academic formation of the educator.

As to the hypothesis of this research study, which consisted of negating that the course of Pedagogy might be able to promote a broad comprehension and process of human formation in its entirety - a concept that was detailed in the aspects of the referred to formation of the educator in his/her personal and relational development (Iprd), in the understanding of his/her activities (Iure) and in the humanely formative dimension of education, school and Pedagogy (Iuesp) - the results obtained refuted this hypothesis, albeit partially, as evidenced by Tables 8 to 16. In fact, the results showed that there are indications that the course of Pedagogy contributes to the process of human formation of its students, in the three aspects mentioned. However, when the age factor is controlled, it is observed that this also contributed to development at least in relation to the Iprd and Iuesp indices.

It is thus demonstrated that not only the course, but also advancing in age would tend to promote greater maturity of the students, which would imply greater personal and relational development and, in turn, a deeper understanding of the human formation associated with education itself. However, it should be emphasized, as also evidenced, that only advancing in age does not in itself lead to such development, for if this were the case, the older first-year students would have more development in the three indices than the younger first-year students, which is something that only occurs with the index of personal and relational development (Table 10). Likewise, if age were the only factor of development, there would be a significant difference between younger and older final-year students, which does not occur (Table 11).

It is reaffirmed, therefore, that the course of Pedagogy contributes to the human formation of its students, although advancing in age also does, at least in relation to the personal and relational development and the formative understanding of education, school and Pedagogy. However, as to the understanding of the formative role of the educator (Iure), the results gave evidence that their development is not related to age, but only to the criterion of being a finalyear student of the course, which reveals, also here, the refutation of the research hypothesis, there being clearer indications, therefore, of the promotion of human formation by the course of Pedagogy regarding this aspect.

Despite the research hypothesis having been refuted, it should be noted that in all the T-tests performed in which there was a statistically significant difference between first- and final-year students, this difference never reached a great amplitude, and did not even reach a standard deviation, which may also be an indication that the possible contribution of the Pedagogy course to personal and relational development, to the appropriate understanding of education as a human formation, and the respective formative function of the educator is not yet as relevant as it should be. Thus, the Pedagogy course analyzed was shown to be more conducive to human formation than was suspected at the beginning of the research study, although not as relevant as would be desirable. 
Finally, it is necessary to point out the limits of this research, recalling its exploratory character. Among the most visible limits, the fact that the sample was not random stands out. This amounted to a single course, precisely that of UFPE. There was no control group, results from which would have been submitted for comparison with a similar group that had not studied Pedagogy. Nor did the research conduct a longitudinal follow-up of students over several years, which would probably be one of the most rigorous ways of verifying the hypothesis, this latter being, however, a more expensive and more time-consuming research study. The instrument formulated, although it served to point out good indications for future research studies, lacks greater validity of the items and consistency of the indices, and therefore needs to be reformulated. Because of all these aspects, none of the results can be generalized for the courses of Pedagogy in Brazil, although the elements found, in an exploratory way, may constitute reasonable indications for future research studies.

\section{References}

Policarpo Junior, J. \& Rodrigues, M. L. F. de M., Princípios orientadores da formação humana: dimensão normativa da educação. Paidéia (Ribeirão Preto), 2010. 20(45), p. 95-103. http://dx.doi.org/10.1590/S0103863X2010000100012.

Rodrigues, N., Educação: da Formação Humana à Construção do Sujeito Ético. Educ. Soc., 2001. 22(76), p. $232-257$. http://dx.doi.org/10.1590/S0101-73302001000300013

Policarpo Junior, J., F. Röhr, Conceptual Grounding of Education as Human Formation - a dialogue between aspects of the field of Education itself and the Buddhist tradition. Education, 2012. 2(5), p. 195-208.

http://dx.doi.org/10.5923/j.edu.20120205.13.

Röhr, F., Espiritualidade e Educação, in: F. Röhr et al., Diálogos em educação e espiritualidade, 2012, Recife: Ed. Universitária da UFPE, p.13-52.

Röhr, F., Educação e Espiritualidade - contribuições para uma compreensão multidimensional da realidade, do homem e da educação, 2013. Campinas, SP: Mercado das Letras.

Ximenes, L. M. e S. Sentidos da Formação Humana Integral - uma comparação preliminar entre três modelos teóricos, in: J. Policarpo Junior (Ed.), O Pensar, o Sentir, o Agir: sentidos da formação humana, 2011, Recife, PE: Instituto de Formação Humana. Electronic book. Available at: http://www.smashwords.com/books/view/306736.

Policarpo Junior, J., A Formação Humana no campo educacional brasileiro: conceituação, limites e possibilidades, in: J. Policarpo Junior (Ed.), Formação Humana, Educação, Espiritualidade: reflexões, 2014, Recife: Instituto de Formação Humana. Electronic book. Available at: https://www.amazon.com.br/Educação-Formação-HumanaEspiritualidade-Reflexões-ebook/dp/B00NOFYSBA/ref=sr_1_1?ie=UTF8\&qid=1498782721\&sr=8$1 \&$ keywords=policarpo+junior.

Gardner, H., Inteligências múltiplas, a teoria na prática, 2000, Porto Alegre, RS: Artmed.

Policarpo Junior, J., Cultura: sentidos da formação humana para o indivíduo e para a sociedade, in: J. Policarpo Junior (Ed.), o Pensar, o Sentir, o Agir: sentidos da formação humana, 2011, Recife, PE: Instituto de Formação Humana. Electronic book. Available at: http://www.smashwords.com/books/view/306736.

Policarpo Junior, J., Um Caminho para uma vida integral e preciosa - reflexões sobre espiritualidade e educação, in: F. Röhr et al., Diálogos em educação e espiritualidade, 2012, Recife: Ed. Universitária da UFPE, p. 81-107.

Jung, C. G., O Eu e o Insconciente, 2007, Rio de Janeiro, RJ: Vozes.

Preece, R., The Wisdom of Imperfection: the challenge of individuation in Buddhist life, 2006, New York, NY: Snow Lion Publications.

Goleman, D. Como Lidar com Emoções Destrutivas - para viver em paz com você e os outros: diálogos com a contribuição do Dalai Lama, 2003, Rio de Janeiro,RJ: Campus.

Elias, M. J. et al., Promoting social and emotional learning: guidelines for educators, 1997, Alexandria, VA (USA): Association for Supervision and Curriculum Development.

Zins, J. E. et al., Building Academic Success on Social and Emotional Learning: What does the research say?, 2004, New York, NY: Teachers College Press. 
Kusché, C. A., M. T. Greenberg, The PATHS Curriculum - Promoting Alternative Thinking Strategies, 1994,7 vols., South Deerfield, MA: Channing L. Bete Co.

Greenberg, M. T., J. Policarpo Junior, Formação Humana e Desenvolvimento Emocional na Educação - o Currículo PATHS, in: IV Colóquio Franco-Brasileiro de Filosofia da Educação, 2008. Proceedings. CD-ROM. Rio de Janeiro: Autêntica.

Kabat-Zinn, J., Coming to Our Senses: Healing Ourselves and the World Through Mindfulness, 2005. New York: Hyperion.

Kornfield, J., Um Caminho com o Coração, 2002. São Paulo, SP: Cultrix.

Dalai Lama, XIV, Beyond Religion: ethics for a whole world, 2012, Boston, MA: Mariner Books; New York: Houghton Mifflin Harcourt.

Biaggio, A. M. B., Lawrence Kohlberg - ética e educação moral, 2002, São Paulo, SP: Moderna.

Gardner, H., O Verdadeiro, o Belo e o Bom - os princípios básicos para uma nova educação, 1999, Rio de Janeiro: Objetiva.

López Quintás, A., Inteligência Criativa - descoberta pessoal de valores, 2004, São Paulo, SP: Paulinas.

United Nations Educational Scientific and Cultural Organization [UNESCO], Learning to be: The world of education today and tomorrow, 1972, Paris: UNESCO.

UNESCO - Asia Pacific Network for International Education and Values Education [APNIEVE], Learning to live together in peace and harmony: values education for peace, human rights, democracy and sustainable development of the Asia-Pacific region, 1998, Bangkok: UNESCO; PROAP.

UNESCO-APNIEVE, Learning to be: A holistic and integrated approach to values education for human development: Core values and the valuing process for developing innovative practices for values education toward international understanding and a culture of peace, 2002, Bangkok: UNESCO Asia and Pacific Regional Bureau for Education.

UNESCO-APNIEVE, Learning to do: Values for learning and working together in a globalized world: an integrated approach to incorporating values education to technical and vocational education and training, 2005, Manila: APNIEVE.

Erikson, E. H., The Life Cycle Completed - a review, 1994, New York: Norton \& Company.

Coelho, M. I. M., Por Que a Educação e a Formação Humana na Contemporaneidade?, in: Coelho, M. I. M. et al., Educação e a Formação Humana - tensões e desafios na contemporaneidade, 2009. Porto Alegre: Artmed.

Severino, A. J., Os Embates da Cidadania: ensaio de uma abordagem filosófica da nova LDB, in: Byzezinski, I (Ed.), LDB Dez Anos Depois - reinterpretação sob diversos olhares, 2008. São Paulo: Cortez.

Galeffi, D. A., Sentidos do Educar Transdisciplinar: o pensar-apropriar, o sentir-partilhar e o agir-transformar, in: J. Policarpo Junior (Ed.), O Pensar, o Sentir, o Agir: sentidos da formação humana, 2011, Recife, PE: Instituto de Formação Humana. Electronic book. Available at: http://www.smashwords.com/books/view/306736.

Brasil, Law n. 9.394, from December 20th 1996 . Lays down the Guidelines and Bases of National Education. Available at: http://www.planalto.gov.br/ccivil_03/Leis/L9394.htm. Accessed on: 29 July 2015.

Conselho Nacional de Educação, Institutes National Curricular Guidelines for the Undergraduate Course in Pedagogy - certificate, Resolução $C N E / C P n^{\circ}$ 1, from May 15 th 2006 . Available at: http://portal.mec.gov.br/cne/arquivos/pdf/rcp01_06.pdf. Accessed on: 29 July 2015.

Arroyo, M. G., Imagens Quebradas - trajetórias e tempos de alunos e mestres, 2007. Petrópolis, RJ: Vozes. Jaeger, W., Paidéia: a formação do homem grego, 2001. São Paulo: Martins Fontes.

Borghi, G., Educação: Razão e Transcendência. in: J. Policarpo Junior (Ed.), Formação Humana, Educação, Espiritualidade: reflexões, 2014, Recife: Instituto de Formação Humana. Electronic book. Available at: https://www.amazon.com.br/Educação-Formação-Humana-Espiritualidade-Reflexõesebook/dp/B00NOFYSBA/ref=sr_1_1?ie=UTF8\&qid=1498782721\&sr=8-1\&keywords=policarpo+junior.

Arendt, H., O Que é Autoridade?, in: Entre o Passado e o Futuro, 1997, São Paulo: Perspectiva.

Libâneo, J. C., S. G. Pimenta, Formação dos Profissionais da Educação: visão crítica e perspectivas de mudanças, in: S. G. Pimenta (Ed.), Pedagogia e Pedagogos: caminhos e perspectivas, 2006. São Paulo: Cortez.

Röhr, F., Reflexões em Torno de um Possível Objeto Epistêmico Próprio da Educação, Pro-Posiç̧̃es, 2006, 18(1), p. 51-70. 
Franco, M. A. S., Pedagogia como Ciência da Educação, 2008, São Paulo: Cortez.

Gauthier, C., M. Tardif, A Pedagogia: teorias e práticas da Antiguidade aos nossos dias, 2010. Petrópolis, RJ: Vozes.

Rovere, M. H., Escola de Valor: Significando a vida e a arte de educar, 2009. São Paulo: Paulus.

Warner, R.M., Applied Statistics: From Bivariate Through Multivariate Techniques, 2012, Thousand Oaks, CA: SAGE Publications.

R Core Team, R: A language and environment for statistical computing, 2015, Vienna, Austria: R Foundation for Statistical Computing. Available at: https://www.R-project.org/.

Moroco, J., T. Garcia-Marques, Qual a fiabilidade do alfa de Cronbach? Questões antigas e soluções modernas, Laboratório de Psicologia, 2006, n. 4, p. 65-90. 